\title{
THE EFFECTS OF SATUREJA HORTENSIS L. EXTRACT ON CISPLATIN- INDUCED BEHAVIORAL ALTERATIONS IN THE TAIL SUSPENSION TEST
}

Igor Kumburovic $^{1 *}$, Davor Kumburovic ${ }^{1 *}$, Sanja Vujovic ${ }^{2}$, Zlata Rajkovic ${ }^{2}$ and Stefan Velickovic ${ }^{2}$

${ }^{1}$ University of Kragujevac, Faculty of Medical Sciences, Department of Physiology, Kragujevac, Serbia

${ }^{2}$ University of Kragujevac, Faculty of Medical Sciences, Department of Dentistry, Kragujevac, Serbia

*Authors Igor Kumburovic and Davor Kumburovic contributed equally to this study as the first author

\section{EFEKTI PRIMENE EKSTRAKTA BILJKE SATUREJA HORTENSIS L. NA BIHEVIORALNE MANIFESTACIJE NEUROTOKSIČNOSTI IZAZVANE CISPLATINOM KOD PACOVA}

Igor Kumburović $^{1^{*}}$, Davor Kumburović ${ }^{1 *}$, Sanja Vujović ${ }^{2}$, Zlata Rajković ${ }^{2}$ Stefan Veličković ${ }^{2}$

${ }^{1}$ Univerzitet u Kragujevcu, Fakultet medicinskih nauka, Katedra za fiziologiju, Kragujevac, Srbija

${ }^{2}$ Univerzitet u Kragujevcu, Fakultet medicinskih nauka, Katedra za stomatologiju, Kragujevac, Srbija

\begin{abstract}
In order to evaluate the effects of Satureja hortensis L. extract on cisplatin-induced behavioral alterations in the tail suspension test (TST), we included 35 male Wistar albino rats in this study, divided into 7 equal groups. Cisplatin was administered (single dose of $7.5 \mathrm{mg} / \mathrm{kg}$, i.p., on the fifth day) alone, and in groups with orally administered (for 10 days) Satureja hortensis L. extract $(50,100$, and $200 \mathrm{mg} / \mathrm{kg})$, and silymarin $(100 \mathrm{mg} / \mathrm{kg})$ in individual groups. The behavioral testing was performed in TST, and the following parameters were obtained: the latency to the first immobility, the number of immobility episodes, and the total duration of immobility. Cisplatin application increased the latency to the first immobility, but decreased the number of immobility episodes and the total duration of immobility. Oral administration of Satureja hortensis L. extract in a dose of $100 \mathrm{mg} / \mathrm{kg}$ attenuated cisplatin-induced alterations, and those effects were similar to silymarin group. The extract in a dose of $200 \mathrm{mg} / \mathrm{kg}$ diminished cisplatin-induced effect only for the total duration of immobility, while in a dose of $50 \mathrm{mg} / \mathrm{kg}$, the extract had no impact on cisplatin effects. Although common use of this methodology would lead to a conclusion that cisplatin produced antidepressant effect, comparison with certain literature data allows the conclusion that this action of cisplatin may be attributed to its anxiogenic action that was attenuated by antioxidant supplementation (Satureja hortensis L.) in an adequate dose (100 $\mathrm{mg} / \mathrm{kg}$ ).
\end{abstract}

Keywords: cisplatin, Satureja hortensis L., anxiety, depression, tail suspension test, rats.

\section{SAŽETAK}

U cilju ispitivanja efekata ekstrakta Satureje hortensis L. na promene ponašanja izazvane cisplatinom u testu kačenja za rep (TKR), u studiju je uključeno 35 muških Wistar albino pacova, podeljenih u 7 jednakih grupa. Cisplatina je primenjivana (pojedinacna doza od $7.5 \mathrm{mg} / \mathrm{kg}$, i.p., petog dana) samostalno, i u grupama sa oralnom primenom (tokom 10 dana) ekstrakta Satureje hortensis L. (50, 100 i $200 \mathrm{mg} / \mathrm{kg})$, i silimarina (100 mg/kg) u pojedinačnim grupama. Bihejvioralno testiranje je sprovedeno $u$ $T K R$, uz određivanje sledećih parametara: vreme do prve imobilnosti, broj epizoda imobilnosti i ukupno trajanje imobilnosti. Primena cisplatine je povećavala vreme do prve imobilnosti, dok je skraćivala broj epizoda imobilnosti i ukupno trajanje imobilnosti. Oralna primena ekstrakta Satureje hortensis L. u dozi od $100 \mathrm{mg} / \mathrm{kg}$ je smanjivala promene izazvane cisplatinom, što je bilo slično efektima u grupi sa silimarinom. Ekstrakt je u dozi od $200 \mathrm{mg} / \mathrm{kg}$ umanjio efekat cisplatine samo za ukupno trajanje $i$ mobilnosti, dok u dozi od $50 \mathrm{mg} / \mathrm{kg}$ ekstrakt nije imao uticaja na efekte cisplatine. Iako bi uobičajena primena ove metodologije dovela do zaključka da cisplatina izaziva antidepresantni efekat, poređenje sa odgovarajućim podacima iz literature omogućava zaključak da se uticaj cipslatine može pripisati njenoj anksiogenoj ulozi, što je bilo umanjeno antioksidantnom suplementacijom (Satureja hortensis L.) u odgovarajućoj dozi (100 mg/kg).

Ključne reči: cisplatina, Satureja hortensis L., anksioznost, depresivnost, test kačenja za rep, pacovi 


\section{INTRODUCTION}

Cisplatin is one of the most widely used anticancer drugs worldwide. Alone or along with other cytostatic agents, cisplatin has been considered a first-line therapy in the treatment of various malignancies for decades, especiallysolid tumors such as ovarian, testicular, head, neck and small cell lung cancers (1).

Despite its well confirmed efficacy in the treatment of a numerous types of cancers, clinical use of cisplatin is often limited because of the dose- and duration-dependent cell resistance. Although, up to date, more than 40 specific types of cisplatin adverse effects have been recognized, according to their incidence and severity, cisplatin side effects have been categorized into seven main groups: nephrotoxicity, ototoxicity, cardiotoxicity, hematological toxicity, hepatotoxicity, gastrointestinal toxicity and neurotoxicity (2). Regardless of the reports that pointed out poor penetration through the blood-brain barrier for the majority of platinum-based compounds (3), it was observed that platinum agents accumulate in the central nervous system (CNS) (4), reaching the highest concentration in specific brain regions such as hippocampus in mice (5). Those findings may be the explanation for the variety of clinical manifestations following cisplatin treatment. Therefore, the following CNS disorders in cisplatin treated patients have been reported: acute blindness and seizures, encephalopathy and stroke-like episodes (6). Also, cisplatin therapy was accompanied with cognitive impairment and emotional dysfunction (7). The cognitive impairment, with the decreased locomotor and exploratory activity, was also observed in cisplatin treated animals $(8,9)$.

Although all kinds of cisplatin-induced toxicities are connected to specific clinical features, the spectrum of underlying pathophysiological mechanisms can be specified in a few principle categories. The most frequently described processes that could be connected to cisplatin-induced toxicities are: the apoptosis (10), DNA damage (11) and inflammation (12). Also, some investigations confirmed that oxidative stress is the key mechanism that disturbs homeostasis following cisplatin treatment and may be the base of its toxicities (13). The prooxidative action of cisplatin comes as a result of combined effects of increased production of reactive oxygen species, such as hydroxyl radical (14), hydrogen peroxide (15), superoxide anion radical $(16)$, and nitrites $(17,18)$, and simultaneous decline in cellular antioxidant capacity, manifested as a decrease in antioxidant enzymes (superoxide dismutase and catalase) activity $(19,20)$, as well as glutathione (21).

The confirmed strong connection between the chemotherapeutics-induced oxidative damage and the clinical manifestations of toxicities in the specific tissues has targeted an antioxidant supplementation as a potentially useful therapeutic approach in the treatment of numerous anticancer drugs adverse effects. In the last decade, the medicinal plants have been widely confirmed as an important source of dietary antioxidants that showed protective effect when applied along with anticancer drugs, by means of diminished oxidative damage, which resulted in attenuation of cytostatic-induced toxicities $(22,23,24)$. Recent study confirmed that Satureja hortensis L., the plant with the high content of antioxidants, such as phenolic compounds, and especially high concentration of rosmarinic acid, showed beneficial antioxidant properties in the treatment of cisplatin-induced nephro- and hepatotoxicity (25).

The aim of this study was to evaluate the behavioral manifestations of cisplatin administration in the TSTin rats. Furthermore, we estimated the potential alterations in behavioral outcome following antioxidant supplementation with Satureja hortensis L. extract in different doses.

\section{MATERIAL AND METHOD}

\section{Animals and treatment}

Animals were housed in seven cages (5 per cage), under standard environmental conditions (temperature $23 \pm 1^{\circ} \mathrm{C}$, humidity $55 \pm 5 \%, 12 / 12 \mathrm{~h}$ light/dark cycle). The animals had access to food and water ad libitum. The rats were randomly divided into 7 experimental groups as follows:

- control group, that received tap water for 10 days and a single dose of $500 \mu \mathrm{L}$ saline on the day 5;

- cisplatin group that received tap water for 10 days and a single dose of cisplatin $(7.5 \mathrm{mg} / \mathrm{kg} \mathrm{b}$. w.) on the day 5;

- CIS+E50 group that received S. hortensis L. extract $(50 \mathrm{mg} / \mathrm{kg} \mathrm{b}$. w.) orally for 10 days and a single dose of cisplatin $(7.5 \mathrm{mg} / \mathrm{kg} \mathrm{b}$. w.) on the day 5 ;

- CIS+E100 group that received S. hortensis L. extract $(100 \mathrm{mg} / \mathrm{kg} \mathrm{b}$. w.) orally for 10 days and a single dose of cisplatin $(7.5 \mathrm{mg} / \mathrm{kg} \mathrm{b}$. w.) on the day 5 ;

- CIS+E200 group that received S. hortensis L. extract $(200 \mathrm{mg} / \mathrm{kg} \mathrm{b}$. w.) orally for 10 days and a single dose of cisplatin $(7.5 \mathrm{mg} / \mathrm{kg} \mathrm{b.} \mathrm{w.)} \mathrm{on} \mathrm{the} \mathrm{day} 5$;

- CIS+SILYMARIN group that received silymarin ( $100 \mathrm{mg} / \mathrm{kg} \mathrm{b}$. w.) orally for 10 days and a single dose of cisplatin $(7.5 \mathrm{mg} / \mathrm{kg} \mathrm{b}$. w.) on the day 5 ;

- E200 group that received S. hortensis L. extract (200 mg/kg b. w.) orally for 10 days.

Cisplatin and saline were administered intraperitoneally, while the extracts were dissolved in tap water. Phytochemical characterization of methanolic extract of S. hortensis L. was previously described in the study by Boroja et al (25).

After completing the described protocols, the animals were placed in the testing room, at approximately $8 \mathrm{a.m}$., in order to accommodate for behavioral testing that usually 
started at 10 a.m. The testing room was acoustically and visually isolated.

\section{Tail suspension test (TST)}

In order to evaluate the behavioral alterations, we performed TST. This test, usually obtained for the estimation of depressive state level, is based on the assumption that the rodents under specific circumstances are expected to put an effort in order to avoid evidently aversive (stressful) stimulus (26). The original apparatus for TST is constructed of metal frame $(0.6 \times 0.6 \mathrm{~m})$ and circular barrier $(25 \mathrm{~cm}$ in diameter $)$ with the central hole (the opening of $15 \mathrm{~mm}$ in diameter) where the tails were slipped through.

Rats were suspended by the tail attached to the adhesive tape (with the barrier $1 \mathrm{~cm}$ below the position of the adhesive tape on the tail, in order to prevent tail climbing), so that they could freely dangle facing downward.

\section{RESULTS}

The applied protocols significantly altered the latency to the first immobility $(\mathrm{F}=11.539, \mathrm{df}=6)$. As shown in Figure 1, the administration of cisplatin in a single dose significantly increased the latency to the first immobility compared to the control group $(\mathrm{p}<0.01)$. S. hortensis L. extract, when applied alone, had no effect on this parameter when compared to the control. However, when applied along with cisplatin, S. hortensis L. extract in a dose of $100 \mathrm{mg} / \mathrm{kg}$ significantly reduced cisplatin-induced augmentation of the latency to the first immobility when compared to the cisplatin group $(p<0.01)$, and the values remained similar compared to the control. On the other hand, both lower (50 mg/kg) and higher (200 mg/kg)
The key point of TST was the quantification of immobility. The immobility was considered as a state with no visible voluntary movement $(<1 \mathrm{~cm})$ of head, body or limbs for at least 5 seconds. Expected involuntary swinging was declared as the state of immobility. The test lasted for six minutes, without any experimenter intervention during the testing. The complete testing was recorded by a video camera. The following parameters were analyzed from the recordings: the latency to the first immobility, the number of immobility episodes and the total duration of immobility.

\section{Statistical Analysis}

The data were presented as means \pm S.E.M. After completing the tests for homogeneity (Levene's) and normality (Shapiro-Wilk), comparisons between the groups were performed using One-way ANOVA, followed by Bonferroni post hoc analysis. Significance was determined at $\mathrm{p}<0.05$. Statistical analysis was performed with SPSS version 20.0 statistical package (IBM SPSS Statistics 20).

dose of $S$. hortensis L. extract failed to significantly attenuate the cisplatin-induced increase in the latency to the first immobility, and this parameter was still significantly higher compared to the control in CIS+E50 group $(\mathrm{p}<0.01)$. Even more, the values of this parameter achieved with the lower dose were statistically below the values observed in the CIS+E100 group $(\mathrm{p}<0.05)$. The impact of simultaneous administration of cisplatin and silymarin was very much alike the observed effect in the CIS+E100 group - significant decline of cisplatin-induced increase in the latency to the first immobility, while preserving the values almost equal with the control group.

Figure 1. The latency to the first immobility in the tail suspension test.

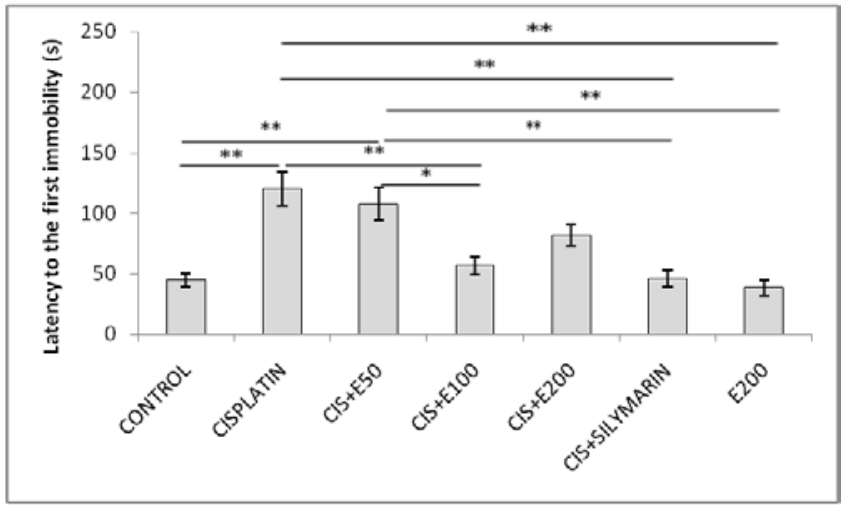

Values are mean \pm standard error of the mean (SEM), $n=5$ per group, *denotes a significant difference $\mathrm{p}<0.05$, **denotes a significant difference $\mathrm{p}<0.01$. 
Like for the latency to the first immobility, the number of immobility episodes in TST was also significantly affected by the applied protocols ( $\mathrm{F}=10.137)$. Cisplatin application resulted in a significant decrease in the number of immobility episodes compared to the control values $(\mathrm{p}<0.01)$. As shown in Figure 2, the decline in this parameter was compensated $(p<0.01)$ with neither the middle dose of S. hortensis L. extract $(100 \mathrm{mg} / \mathrm{kg})$, nor with the higher $(200 \mathrm{mg} / \mathrm{kg})$ or the lower $(50 \mathrm{mg} / \mathrm{kg}$ ) dose of S. hortensis L. extract. It should be noticed that the increase in the number of immobility episodes observed following simultaneous administration of cisplatin and S. hortensis L. extract in a dose of $100 \mathrm{mg} / \mathrm{kg}$ was even statistically significant when compared to the CIS+E50 group $(p<0.05)$. Again, the effect obtained with the middle dose of S. hortensis L. extract was very similar to the one achieved with the same concentration of silymarin when applied along with cisplatin. Also, the number of immobility episodes was not significantly affected by S. hortensis L. extract in a dose of $200 \mathrm{mg} / \mathrm{kg}$, when applied alone, compared to the control group.

Figure 2. The number of episodes of immobility in the tail suspension test.

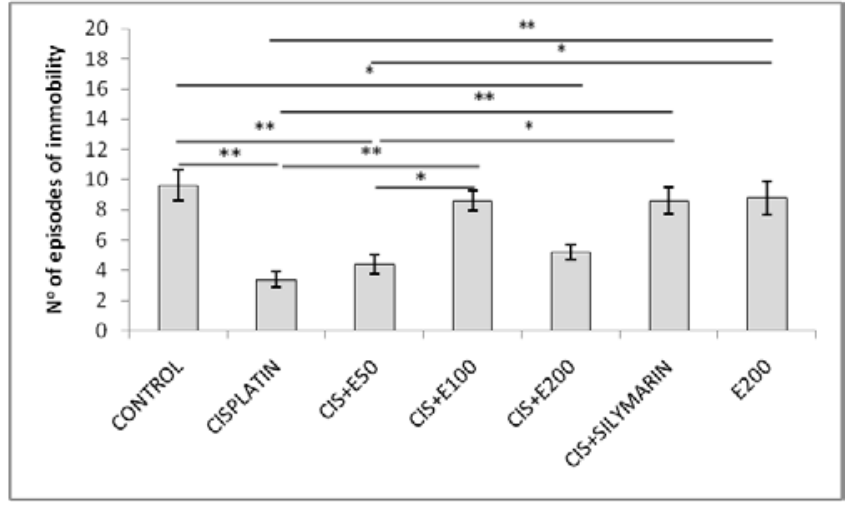

Values are mean \pm standard error of the mean (SEM), $n=5$ per group,

$*$ denotes a significant difference $\mathrm{p}<0.05$, **denotes a significant difference $\mathrm{p}<0.01$.

Finally, as shown in Figure 3, all the applied protocols also had significant impact on the total duration of immobility $(\mathrm{F}=16.271)$. Administration of cisplatin in a single dose $(7.5 \mathrm{mg} / \mathrm{kg})$ resulted in a significant decline in the immobility duration compared to the control $(p<0.01)$. Although the individual administration of S. hortensis L. extract did not result in a significant change in the total duration of immobility, the administration of S. hortensis L. extract in the doses of 100 and $200 \mathrm{mg} / \mathrm{kg}$ significantly augmented the cisplatininduced decrease in the total immobility $(\mathrm{p}<0.01)$. Only the values achieved in the CIS+E200 group remained significantly below the control values $(\mathrm{p}<0.01)$. The lowest dose of extract $(50 \mathrm{mg} / \mathrm{kg})$ failed to reduce the cisplatin-induced reduction in the total duration of immobility. The impact of simultaneous administration of cisplatin and silymarin on the duration of immobility in TST resembled the effects observed with the middle and the highest dose of S. hortensis L. extract. However, the total duration of immobility achieved in the CIS+SILYMARIN group, unlike the CIS+E100 group, remained statistically below the control values $(\mathrm{p}<0.01)$.

Figure 3. The total duration of immobility in the tail suspension test.

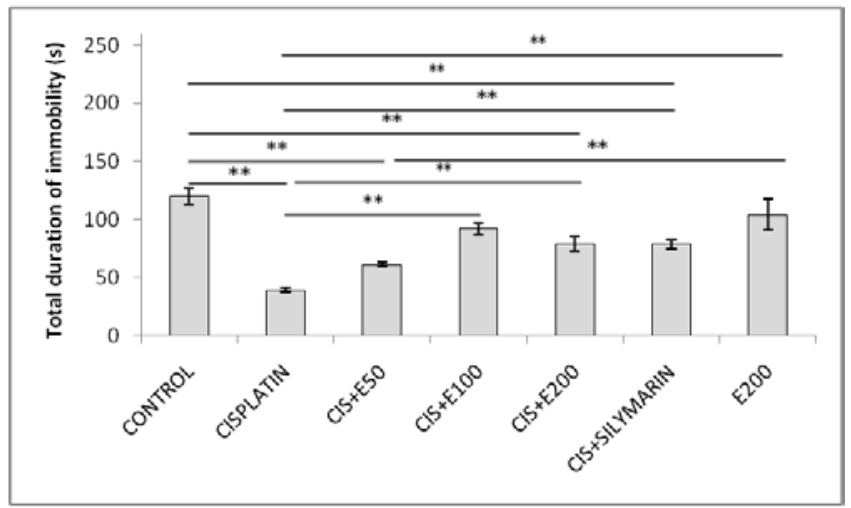

Values are mean \pm standard error of the mean (SEM), $n=5$ per group, $* *$ denotes a significant difference $\mathrm{p}<0.01$. 


\section{DISCUSSION}

Beside its unquestionable anticancer properties, cisplatinbased chemotherapy is usually limited by numerous side effects (27), including clinical manifestations of neurotoxicity (28). Many cisplatin-induced toxicities are accompanied with an evident mitochondrial dysfunction and oxidative damage in various tissues (29). Therefore, any of therapeutic approaches that may prevent the cisplatin-induced increase in oxidative stress, as a trigger factor for tissue damage, may be potentially useful as a supplementary treatment along with cisplatin therapy.

One of the most recently reported manifestations of adverse effect of cisplatin on CNS has clinical form with characteristics of increased depressive state level (30). The prodepressant action of cisplatin, by means of behavioral tests results, in that study (performed on rats) was accompanied with prooxidant alterations in both cortex and hippocampus. Also, neuronal degeneration in hippocampus paralleled the decline in BDNF and GABA content, as well as the increase in hippocampal glutamate (30).

However, the results obtained in our study may lead to a conclusion that cisplatin administration had the antidepressant effect by means of behavioral patterns observed in TST. On the other hand, the literature data offer a recently established possibility that the estimation of depressive state level can be substantially mimicked with significant alterations in anxiety levels. Namely, the specific mood disorders that are dominantly characterized with strong anxiogenic features may overcome the prodepressant action resulting in inadequately pronounced antidepressant effect (31). The offered explanation is that increased motor activity observed in the tests for depressive level estimation (such as TST) may rather be considered as the behavioral outcome of anxiety-induced overreacting than antidepressant action. When comparing the results for prodepressant action of cisplatin (30) and increased locomotor response in TST observed in this study, we must take into consideration two important information. Firstly, those two studies were performed with the significantly different protocols: the prodepressant effect was reported in the study with the chronic exposure to cisplatin (10 weeks), while the opposite effect on depressive level was obtained in the study with a single dose of cisplatin. Secondly, the recent study of Kumburovic et al. (32) confirmed the extremely strong anxiogenic response to a single dose of cisplatin, as the earliest behavioral manifestation of cisplatin administration. Therefore, we can conclude that the results of those two studies are not the opposite or even contradictory. It seems that the cisplatin impact in certain brain regions involved in mood regulation that includes numerous biochemical and morphological alterations is very complex. It seems that the cisplatin action in the CNS, by means of behavioral changes, starts with predominantly anxiogenic response followed by prodepressant action if the cisplatin treatment lasts long enough. Therefore, the behavioral outcome of cisplatininduced neurotoxicity has strong time dependent characteristics. In addition, it is not surprising that beneficial effects of antioxidant supplementation following cisplatin therapy also strongly depend on the principle behavioral outcome. Namely, the benefits obtained with $S$. hortensis L. extract in this study were manifested not by prodepressant action, but as the clear anxiolytic-like response to antioxidant supplementation. Our results are in line with previously reported beneficial action of various antioxidant sources on cisplatininduced neurotoxicity with clinical manifestations that involve increased anxiety levels $(8,9)$.

\section{CONCLUSION}

In summary, the neurotoxic manifestations of cisplatin treatment as observed in this study, manifested by anxiogenic response in TST, can be significantly attenuated by S. hortensis L. extract supplementation. So, according to the results of our study, it seems that antioxidant supplementation may be useful in diminishing cisplatin-induced neurotoxicity.

\section{ACKNOWLEDGMENTS}

This paper was supported by the Faculty of Medical Sciences (JP 06/18, 01/19), University of Kragujevac.

\section{CONFLICT OF INTERESTS}

None of the authors of the present study have any actual or potential conflicts of interest to disclose, including financial, personal, or other relationships with specific persons or organisations. 


\section{REFERENCE}

1. Rosic G, Joksimovic J, Selakovic D, Jakovljevic V, Zivkovic V, Srejovic I, Djuric M, Djuric D. (2018). The Beneficial Effects of Sulfur-containing Amino Acids on Cisplatin induced Cardiotoxicity and Neurotoxicity in Rodents. Curr Med Chem, 25(3), 391-403.

2. Oun R, Moussa YE, Wheate NJ. (2018). The side effects of platinum-based chemotherapy drugs: a review for chemists. Dalton Trans, 47(19), 6645-53. Erratum in: Dalton Trans, 47(23), 7848.

3. McKeage MJ, Hsu T, Screnci D, Haddad G, Baguley BC. (2001). Nucleolar damage correlates with neurotoxicity induced by different platinum drugs. Br J Cancer, 85(8), 1219-25.

4. Nakagawa H, Fujita T, Kubo S, Tokiyoshi K, Yamada M, Kanayama T, Hagiwara Y, Nakanomyo H, Hiraoka M. (1996). Difference in CDDP penetration into CSF between elective intraarterial chemotherapy in patients with malignant glioma and intravenous or intracarotid administration in patients with metastatic brain tumor. Cancer Chemother Pharmacol, 37(4), 317-26.

5. Koppen C, Reifschneider O, Castanheira I, Sperling M, Karst U, Ciarimboli G. (2015). Quantitative imaging of platinum based on laser ablation-inductively coupled plasmamass spectrometry to investigate toxic side effects of cisplatin. Metallomics, 7(12), 1595-603.

6. Gulec M, Oral E, Dursun OB, Yucel A, Hacimuftuoglu A, Akcay F, Suleyman H. (2013). Mirtazapine protects against cisplatin-induced oxidative stress and DNA damage in the rat brain. Psychiatry Clin Neurosci, 67(1):50-8.

7. Filley CM. (1999). Toxic leukoencephalopathy. Clin Neuropharmacol, 22(5), 249-60.

8. Shabani M, Nazeri M, Parsania S, Razavinasab M, Zangiabadi N, Esmaeilpour K, Abareghi F. (2012). Walnut consumption protects rats against cisplatin-induced neurotoxicity. Neurotoxicology, 33(5), 1314-21.

9. Golchin L, Shabani M, Harandi S, Razavinasab M. (2015). Pistachio supplementation attenuates motor and cognition impairments induced by cisplatin or vincristine in rats. Adv Biomed Res, 4, 92.

10. Kong D, Zhuo L, Gao C, Shi S, Wang N, Huang Z, Li W, Hao L. (2013). Erythropoietin protects against cisplatin-induced nephrotoxicity by attenuating endoplasmic reticulum stress-induced apoptosis. J Nephrol, 26(1), 219-27.

11. Li XB, Schluesener HJ. (2006). Therapeutic effects of cisplatin on rat experimental autoimmune encephalomyelitis. Arch Immunol Ther Exp (Warsz), 54(1), 51-3.

12. Kang KP, Kim DH, Jung YJ, Lee AS, Lee S, Lee SY, Jang KY, Sung MJ, Park SK, Kim W. (2009). Alphalipoic acid attenuates cisplatin-induced acute kidney injury in mice by suppressing renal inflammation. Nephrol Dial Transplant, 24(10), 3012-20.

13. Karasawa T, Steyger PS. (2015). An integrated view of cisplatin-induced nephrotoxicity and ototoxicity. Toxicol Lett, 237(3), 219-27.
14. Shino Y, Itoh Y, Kubota T, Yano T, Sendo T, Oishi R. (2003). Role of poly (ADP-ribose) polymerase in cisplatin induced injury in LLC-PK1 cells. Free Radic Biol Med, 35, 966-77.

15. Kadikoylu G, Bolaman Z, Demir S, Balkaya M, Akalin N, Enli Y. (2004). The Effects of desferrioxamine on cisplatin induced lipid peroxidation and the activities of antioxidant enzymes in rat kidneys. Hum Exp Toxicol, 23(1), 29-34.

16. Davis CA, Nick HS, Agarwal A. (2001). Manganese superoxide dismutase attenuates Cisplatin-induced renal injury: importance of superoxide. J Am Soc Nephrol, 12(12), 2683-90.

17. Rosic G, Srejovic I, Zivkovic V, Selakovic D, Joksimovic J, Jakovljevic V. (2015). The effects of N-acetylcysteine on cisplatin-induced cardiotoxicity on isolated rat hearts after short-term global ischemia. Tox Rep, 2, 996-1006.

18. Rosic G, Selakovic D, Joksimovic J, Srejovic I, Zivkovic V, Tatalovic N, Orescanin-Dusic Z, Mitrovic S, Ilic M, Jakovljevic V. (2016). The effects of N-acetylcysteine on cisplatin-induced changes of cardiodynamic parameters within coronary autoregulation range in isolated rat hearts. Toxicol Lett, 242, 34-46.

19. Almaghrabi OA. (2015). Molecular and biochemical investigations on the effect of quercetin on oxidative stress induced by cisplatin in rat kidney. Saudi J Biol Sci, 22(2), 227-31.

20. Yuce A, Atessahin A, Ceribasi AO, Aksakal M. (2007). Ellagic acid prevents cisplatin-induced oxidative stress in liver and heart tissue of rats. Basic Clin Pharmacol Toxicol, 101(5), 345-9.

21. Noori S, Mahboob T. (2010). Antioxidant effect of carnosine pretreatment on cisplatin-induced renal oxidative stress in rats. Indian Clin Biochem, 25(1), 86-91.

22. Moon JH, Shin JS, Kim JB, Baek NI, Cho YW, Lee YS, Kay HY, Kim SD, Lee KT. (2013). Protective effects of 6-hydroxy-1-methylindole-3-acetonitrile on cisplatininduced oxidative nephrotoxicity via Nrf2 inactivation. Food Chem Toxicol, 62, 159-66.

23. Singh TD, Meitei HT, Sharma AL, Robinson A, Singh LS, Singh TR. (2015). Anticancer properties and enhancement of therapeutic potential of cisplatin by leaf extract of Zanthoxylum armatum DC. Biol Res, 48, 46.

24. Yadav YC. (2015). Hepatoprotective effect of Ficus religiosa latex on cisplatin induced liver injury in Wistar rats. Rev Bras Farmacogn 25, 278-83.

25. Boroja T, Katanić J, Rosić G, Selaković D, Joksimović J, Mišić D, Stanković V, Jovičić N, Mihailović V. (2018). Summer savory (Satureja hortensis L.) extract: Phytochemical profile and modulation of cisplatin-induced liver, renal and testicular toxicity. Food Chem Toxicol, 118, 252-63.

26. Chermat R, Thierry B, Mico JA, Steru L, Simon P. (1986). Adaptation of the tail suspension test to the rat. J Pharmacol, 17(3), 348-50. 
27. Astolfi L, Ghiselli S, Guaran V, Chicca M, Simoni E, Olivetto E, Lelli G, Martini A. (2013). Correlation of adverse effects of cisplatin administration in patients affected by solid tumours: a retrospective evaluation. Oncol Rep, 29(4), 1285-92.

28. Kanat O, Ertas H, Caner B. (2017). Platinum-induced neurotoxicity: A review of possible mechanisms. World J Clin Oncol, 8(4), 329-35.

29. Bobylev I, Joshi AR, Barham M, Neiss WF, Lehmann HC. (2018). Depletion of Mitofusin-2 Causes Mitochondrial Damage in Cisplatin-Induced Neuropathy. Mol Neurobiol, 55(2), 1227-35.
30. Abdelkader NF, Saad MA, Abdelsalam RM. (2017). Neuroprotective effect of nebivolol against cisplatin-associated depressive-like behavior in rats. J Neurochem, 141(3), 449-60.

31. Rosic G, Joksimovic J, Selakovic D, Milovanovic D, Jakovljevic V. (2014). Anxiogenic effects of chronic exposure to nandrolone decanoate (ND) at supraphysiological dose in rats: a brief report. Neuro Endocrinol Lett, 35(8), 703-10.

32. Kumburovic I, Selakovic D, Juric T, Jovicic N, Mihailovic V, Stankovic JK, Sreckovic N, Kumburovic D, Jakovljevic V, Rosic G. (2019) Antioxidant Effects of Satureja hortensis L. Attenuate the Anxiogenic Effect of Cisplatin in Rats. Oxid Med Cell Longev. 2019:8307196 